\title{
Determination of regional emission factors for the power sector in Southern Africa
}

\author{
Peter P Zhou \\ EECG Consultants Pty Ltd, Gaborone, Botswana
}

\section{Francis D Yamba}

Centre for Energy, Environment and Engineering of Zambia, Lusaka, Zambia

\section{Philip Lloyd}

Energy Institute, Cape Peninsula University of Technology, Cape Town, South Africa

\section{Lovemore Nyahuma}

Zimbabwe Electricity Supply Authority, Harare, Zimbabwe

Cornelius Mzezewa

Consultant, Zimbabwe

\section{Fredrick Kipondya}

Fredka International Ltd, Tanzania

\section{John Keir}

Eskom, Johannesburg, South Africa

\section{Joe Asamoah}

Enerwise Pty Ltd, Johannesburg, South Africa

\section{Henry Simonsen}

Enerwise Pty Ltd, Johannesburg, South Africa

\begin{abstract}
The generation of power within Southern Africa is reviewed. A study is described in which the emission factors for $\mathrm{CO}_{2}$ and $\mathrm{NO}_{x}$ were determined experimentally across a wide range of power stations and technologies, and compared to the IPCC default factors. It was found that the $\mathrm{CO}_{2}$ emission factors tended to be at the upper end of the IPCC default range, whereas the NOx emission factors were generally below the low end. The results from South Africa tend to dominate the regional picture at present, but this is likely to change in the near future, as Botswana has announced plans to introduce over $4000 \mathrm{MWe}$ of coal-fired power stations.
\end{abstract}

Keywords: SADC, climate change, power sector, emission factor, greenhouse gas

\section{Introduction}

The assessment of the impact of greenhouse gases on the environment requires a reasonably accurate assessment of the quantities of greenhouse gases being emitted into the atmosphere from various sources. The reliability of such emission estimates depends on the accuracy of both the activity data and emission factors. The Intergovernmental Panel on Climate Change (IPCC) (IPCC, 2006) identifies three approaches to estimation:

- Tier 1 - using the quantity of fuel employed and a default emission factor for the source category;

- Tier 2 - using the quantity of fuel combusted and a country-specific emission factor for the source category and fuel for each gas;

- Tier 3 - as Tier 2 but using technology-specific emission factors for the source category and fuel for each gas.

The purpose of this study was therefore to develop 
country-specific emission factors, which would also allow comparison with the default factors employed by the IPCC. Many the national inventories for SubSaharan Africa, including that for the power sector, have been based on the previous (1996) default emission factors (IPCC, 1996). The study was initiated in 2002. The project was supported under Eskom's Southern Africa Climate Change Research Initiative, launched in 1999, which has the following objectives:

- To provide assistance to the Southern African Development Community (SADC) countries and power utilities within those countries to meet their obligations in terms of the United Nations Framework Convention for Climate Change;

- To ensure compatibility of regional efforts to address economic growth and achieve sustainable development, while addressing the requirements of the United Nations Framework Convention for Climate Change;

- To analyze the potential risks to regional utilities under the threat of a climate change response, and to develop adaptation measures to offset such risks;

- To map out cleaner power sector alternatives in anticipation of any international policy to reduce the dependence on greenhouse gas emitting fossil fuels like coal, which is the dominant primary energy resource used for power generation in the SADC region; and

- To be ready for business opportunities, which may present themselves under the Kyoto Protocol flexible mechanisms such as the Clean Development Mechanism (CDM).

The emphasis of this research project was on carbon dioxide $\left(\mathrm{CO}_{2}\right)$, which is the key greenhouse gas that is mandatory for the preparation of National Communications and CDM baselines. Emission factors for oxides of nitrogen $\left(\mathrm{NO}_{\mathrm{x}}\right)$, emission factors from coal, diesel power plant combustion as well as methane $\left(\mathrm{CH}_{4}\right)$ from coal mining were also determined. Emission factors are expressed as kg emissions/per energy unit of fuel (fuelbased) and $\mathrm{kg}$ emissions/unit of electrical energy generated (plant/energy based).

Other objectives of the project included:

- Systemizing power sector data and knowledge on regional power sector characteristics;

- Capacity building in the region for climate change research, development of a national greenhouse gas inventory and the successful formulation of CDM type projects;

- The establishment of capacity for continued improvements of emission factors in the SADC region;

- The building of capacity and creation of interest within regional utilities in plant data and emission management;
- The development of an organizational model for improving emission factors that could be applied in other sectors and regions.

- The building of a network for climate change research institutions in the region; and

- Contributions to the IPCC emission factor database.

\section{Overview of power generation in the SADC}

The SADC region is supplied by $42.5 \mathrm{GW}$ of thermal power, $6.5 \mathrm{GW}$ of hydropower and $1.8 \mathrm{GW}$ of nuclear power (Kritzinger-van Niekerk et al, 2002). The regional electricity supply is dominated by thermal generation $(79.9 \%)$ with $77.7 \%$ being derived from coal-fired power plants (Kritzinger-van Niekerk and Moreira, 2002).

South Africa is the dominant producer, with 42.9GW of capacity (Eskom, 2006). It obtains $94.1 \%$ of its generation capacity from coal and the remainder from nuclear $(4.3 \%)$, and diesel $(1.5 \%)$ (Digest of South African Energy Statistics 2005). Other countries, where thermal generation capacity makes a significant proportion of the national power capacity include Botswana 132 MW (100\%) (Mbendi, 2007) and Zimbabwe 1295 MW (61\%) (Mbendi, 2007). Botswana has announced plans to increase its coal-fired generation by over $3700 \mathrm{MW}$, primarily for export (Fossil Fuel Foundation, 2008). Namibia has the 120 MW Van Eck thermal power station, the 320 MW Ruacana hydroelectric station, and the $24 \mathrm{MW}$ Paratus diesel plant, but the thermal stations are primarily for standby capacity. The transmission grid is linked to the South African and Zambian grids. Production in 2000 totalled 30 million $\mathrm{kWh}$, of which $2 \%$ was from fossil fuels and $98 \%$ from hydropower. Over half the electricity was exported (Nationsencyclopedia, 2007)

It is clear that coal-fired thermal plants are dominant in those countries where the fuel is locally available i.e. in South Africa, Botswana and Zimbabwe. The capacities of utility owned coalfired power stations range from $6 \mathrm{MW}$ to over 3840 MW.

Most of the diesel power stations considered in the study have capacities ranging from $20 \mathrm{~kW}$ to 10 MW and generally supply isolated demand centres remote from the national grid. Some of these diesel plants comprise standby generators, which provide backup when there is an outage on the grid.

The gas turbines in operation in the region are usually somewhat larger than diesel plants, with a range of $3 \mathrm{MW}$ to $180 \mathrm{MW}$, the larger units being operated in South Africa (171 MW), Angola (93 MW), Mozambique (79 MW), and Tanzania (18.5 MW) (Southern Centre, 1998). The use of gas for power generation in the region is currently limited but is likely to increase in countries with natural gas reserves that include Angola, Mozambique, Nam- 
ibia and South Africa. 2 GW of additional capacity is being installed in South Africa (Eskom, 2006).

There are also a number of countries with significant proportion of hydro-generation capacity, namely the Democratic Republic of Congo (DRC) (99\%), Mozambique (95\%), Zambia (93\%), and Tanzania (83\%). The sources of energy in the SADC are summarised in Table 1.

\section{Outline of study}

The study was carried out on coal-fired and diesel stations, in South Africa (coal), Tanzania (coal and diesel), Zambia (diesel), Zimbabwe (coal), Botswana (coal), Namibia (diesel) and Mozambique (diesel). The prevalence of coal mining in the region also called for an attempt to estimate coal-mining methane emission factors.

The study was undertaken in three phases between 2002 and 2005. Under Phase 1, project teams in South Africa, Tanzania, Zambia and Zimbabwe undertook an inventory of thermal power plants characteristics with regard to age, capacity, technology, and operating conditions; followed by the determination of emission factors based on the IPCC (IPCC, 1996) methodology and Fenger et al. (1990). To determine country/regional fuel based emission factors using these methods, data on fuel consumption, carbon content and heat value of the fuels were required. Phase 1 therefore also involved the collection of data on fuel consumption and corresponding electricity generation in order to verify plant efficiencies.

Phase 2 involved determinations of $\mathrm{CO}_{2}$ and NOx for coal-fired and diesel plants based on flue gas measurements. A methane emission factor from underground mining in Zimbabwe was determined from secondary data on methane concentrations monitored at the Hwange coal mine in Zimbabwe. Phase 3 continued on the same measurements as in Phase 2 with an additional measurement made in Namibia (diesel), Botswana (coal) and Mozambique (diesel). For Mozambique, the fuel based emission factor was assumed to be similar to that of diesel used in the region (e.g. Zambia) and the plant based emission factor was then derived using the plant efficiency.

The names and fuel types of the coal-fired and diesel power stations covered in the research are given in Table 2.

Under Phase 1, data collection was undertaken for all of the 11 large coal-fired power stations (1900 MW to 3840 MW) in South Africa, 4 medium coal-fired power stations in Zimbabwe (120 MW to $920 \mathrm{MW})$ and one small coal-fired power station (6 MW) in Tanzania. For diesel plants, data was collected for 11 diesel power stations (0.5 MW to 3.5 $\mathrm{MW}$ ) in Zambia, and a suite of 7 diesel (1 MW to 8 MW), 2-jet fuel (15 MW to $40 \mathrm{MW}$ ) and 2 petrol (1 MW to $8 \mathrm{MW}$ ) power stations in Tanzania.

In Phase 2, flue gases were measured at Kendal (3840 MW), Lethabo (3558 MW) and Arnot (1980 MW) power stations in South Africa, at Bulawayo (120 MW), Harare (135 MW) and Hwange (920 MW) power stations in Zimbabwe, at Kiwira power station (6 MW) in Tanzania and at Morupule power station (132 MW) in Botswana. At the time of measurements, coal quality and plant efficiencies were noted.

Similar measurements were undertaken for diesel plants at Kaoma $(3467 \mathrm{~kW})$ and Luangwa $(540 \mathrm{~kW})$ in Zambia. In Tanzania, measurements were undertaken at Kigoma (4.08 MW), Mtwara (4.94 MW), Njombe (1.28 MW) and Songea. In Namibia, emission factors were determined at

Table 1: Electricity generation mix in Southern African countries (MWe) Source: www.sapp.co.zw and links

\begin{tabular}{|c|c|c|c|c|c|c|c|}
\hline Country & Max. demand & Coal & Diesel & Gas & Hydro & Nuclear & Total capacity \\
\hline$\overline{\text { Angola }}$ & 397 & & 135 & & 610 & & 745 \\
\hline Botswana & 434 & 132 & & & & & 132 \\
\hline Lesotho & 90 & & & & 72 & & 72 \\
\hline Malawi & 242 & & & & 285 & & 285 \\
\hline Mozambique & 285 & & 127 & & 2385 & & 2512 \\
\hline Namibia & 491 & 120 & 24 & & 149 & & 293 \\
\hline South Africa & 33461 & 39863 & 296 & 342 & 600 & 1840 & 42941 \\
\hline Swaziland & 172 & 10 & & & 41 & & 51 \\
\hline Tanzania & 509 & & 80 & & 561 & & 641 \\
\hline Zambia & 1330 & & 125 & & 1716 & & 1841 \\
\hline Zimbabwe & 2066 & 1225 & & & 750 & & 1975 \\
\hline$\overline{\mathrm{DRC}}$ & 1012 & & 38 & & 2404 & & 2442 \\
\hline TOTAL & 40489 & 41350 & 825 & 342 & 9573 & 1840 & 53930 \\
\hline
\end{tabular}


Table 2: Characteristics of power stations studied

\begin{tabular}{|c|c|c|c|c|c|c|}
\hline Country & Power stations & Fuel type & Technology & $\begin{array}{c}\text { Capacity } \\
\text { (MW) }\end{array}$ & Load factor & $\begin{array}{l}\text { Thermal } \\
\text { efficiency }\end{array}$ \\
\hline \multirow[t]{11}{*}{ South Africa } & Arnot & Coal & PF-Tangential firing & 3450 & $66 \%$ & $35 \%$ \\
\hline & Lethabo & Coal & PF-Wall Firing & 3558 & $62 \%$ & $35 \%$ \\
\hline & Kendal & Coal & PF-Tangential firing & 3840 & $63 \%$ & $34 \%$ \\
\hline & Matimba & Coal & PF-Tangential firing & 3690 & $75 \%$ & $34 \%$ \\
\hline & Duvha & Coal & PF-Wall Firing & 3450 & $66 \%$ & $35 \%$ \\
\hline & Tutuka & Coal & PF-Wall Firing & 3510 & $56 \%$ & $35 \%$ \\
\hline & Matla & Coal & PF-Wall Firing & 3450 & $63 \%$ & $35 \%$ \\
\hline & Majuba-wet & Coal & PF-Wall Firing & 2007 & $63 \%$ & $34 \%$ \\
\hline & Majuba-Dry & Coal & PF-Wall Firing & 1836 & $39 \%$ & $32 \%$ \\
\hline & Kriel & Coal & PF-Wall Firing & 2850 & $64 \%$ & $35 \%$ \\
\hline & Hendrina & Coal & PF-Wall Firing & 1900 & $66 \%$ & $32 \%$ \\
\hline \multirow[t]{5}{*}{ Tanzania } & Kiwira & Coal & Chain grate & 6 & & $12 \%$ \\
\hline & Kigoma & Diesel & & 4.08 & & $30 \%$ \\
\hline & Mtwara & Diesel & & 4.94 & & $34 \%$ \\
\hline & Njombe & Diesel & & 1.28 & & $32 \%$ \\
\hline & Songea & Diesel & & 2.42 & & $39 \%$ \\
\hline Zimbabwe & Hwange & Coal & PF 4x120MW & & & \\
\hline \multirow[t]{3}{*}{$2 \times 220 M W$} & 920 & $65 \%$ & $31.8 \%$ & & & \\
\hline & Harare 3 & Coal & PF $2 \times 30 M W$ & 60 & $17 \%$ & $20.1 \%$ \\
\hline & Harare 2 & Coal & Chain grate $2 \times 7.5$, & & & \\
\hline \multirow[t]{2}{*}{10 , and $20 \mathrm{MW}$} & 75 & $17 \%$ & $20.1 \%$ & & & \\
\hline & Munyati & Coal & Chain grate $5 \times 20$ & & & \\
\hline \multirow[t]{2}{*}{ MW, 2x10MW } & 120 & $17 \%$ & $20 \%$ & & & \\
\hline & Bulawayo & Coal & Chain grate $3 \times 30$ & & & \\
\hline MW, 2x15MW & 120 & $17 \%$ & $19.3 \%$ & & & \\
\hline Botswana & Morupule & Coal & Chain grate, $4 \times 33 \mathrm{MW}$ & 132 & $85 \%$ & $31.6 \%$ \\
\hline \multirow[t]{13}{*}{ Zambia } & Lukulu & Diesel & & 0.540 & & $21 \%$ \\
\hline & & Diesel & & 1.130 & & $23 \%$ \\
\hline & Kasempa & Diesel & & 0.795 & & $34 \%$ \\
\hline & Kabompo & Diesel & & 0.750 & & $35 \%$ \\
\hline & Mwinilunga & Diesel & & 0.750 & & $39 \%$ \\
\hline & & Diesel & & 0.790 & & $36 \%$ \\
\hline & Zambezi & Diesel & & 0.750 & & $36 \%$ \\
\hline & Mufumbwe & Diesel & & 0.640 & & $28 \%$ \\
\hline & Kaoma & Diesel & & 1.067 & & $31 \%$ \\
\hline & & Diesel & & 2.400 & & $29 \%$ \\
\hline & Kaputa & Diesel & & 0.795 & & $24 \%$ \\
\hline & Luangwa & Diesel & & 0.540 & & $19 \%$ \\
\hline & Chama & Diesel & & 0.528 & & $8 \%$ \\
\hline Mozambique & Massingir & Diesel & & 0.296 & $60 \%$ & $30 \%$ \\
\hline Namibia & Paratus & Diesel & & 24 & & $32.9 \%$ \\
\hline
\end{tabular}

Paratus diesel power station (24 MW) in Walvis Bay. In Mozambique, emission factors were determined for Massingir diesel power station (296 kW). The flue gas measurements for coal-fired power stations resulted in emission factors for $\mathrm{CO}_{2}$ and $\mathrm{NO}_{\mathrm{x}}$, while results for diesel plants were only for $\mathrm{CO}_{2}$.

It should be noted that while the above has con- centrated on the installed capacity, account must also be taken of the load factors in determining the total annual emissions. In this study, however, the accent was on the emission factors themselves, so the results are expressed in terms of emissions per MW electrical.

A Lancom III portable flue gas analyzer, with the 
Table 3: Coal qualities studied

\begin{tabular}{|c|c|c|c|c|c|c|c|}
\hline Country & Power station & $C \%$ & $N \%$ & Ash\% & GCV $(\mathrm{MJ} / \mathrm{kg})$ & $\mathrm{NCV}(\mathrm{MJ} / \mathrm{kg})$ & Type \\
\hline \multirow[t]{4}{*}{ South Africa } & Kendal & 51.7 & 1.12 & 27.8 & 19.9 & 19.8 & Bit \\
\hline & Kendal & 52.5 & 1.14 & 26.8 & 20.2 & 20.1 & Bit \\
\hline & Lethabo & 40.3 & 0.82 & 37.2 & 14.9 & 14.8 & Sub Bit \\
\hline & Arnot & 57.2 & 1.42 & 20.9 & 22.8 & 21.5 & Bit \\
\hline Tanzania & Kiwira & 51.0 & 1.15 & 26.5 & 18.5 & 17.8 & Sub Bit \\
\hline \multirow[t]{3}{*}{ Zimbabwe } & Bulawayo & 76.5 & 1.72 & 14.6 & 29.9 & 28.4 & Bit \\
\hline & Harare & 76.5 & 1.72 & 14.6 & 29.9 & 28.4 & Bit \\
\hline & Hwange & 68.3 & 1.88 & 24.7 & 24.2 & 22.9 & Sub Bit \\
\hline Botswana & Morupule & 63.9 & 1.4 & 18.7 & 24.0 & 22.7 & Sub Bit \\
\hline
\end{tabular}

GCV - Gross calorific value; NCV - Net calorific value, Bit - bituminous coal; Sub Bit - Sub bituminous coals

Table 4: Comparison of Zambian diesel with IPCC default composition

\begin{tabular}{lcccc}
\hline Parameter & IPCC Default & Country specific & Difference & Percentage difference \\
\hline Net calorific value (GJ/tonne) & 43.33 & 43.06 & 0.27 & $0.62 \%$ \\
\hline $\begin{array}{l}\text { Density }\left(\mathrm{kg} / \mathrm{m}^{3} \text { ) }\right. \\
\text { (Standard value) }\end{array}$ & $\begin{array}{c}0.840 \\
\text { (Average used 0.845) }\end{array}$ & 0.005 & $0.60 \%$ \\
\hline Carbon content & $\begin{array}{c}0.87-0.90^{*} \\
\text { (Average }=0.885)\end{array}$ & $0.90^{* *}$ & 0.015 & $1.67 \%$ \\
\hline Carbon oxidized & 0.99 & 0.99 (assumed) & - & - \\
* Typical values of most diesel fuels based on different chemical formulation & & \\
** Value based on Zambia's diesel chemical formulation of $\mathrm{C}_{14} \mathrm{H}_{18}$ & \\
\hline
\end{tabular}

capability to monitor up to 9 gases and including data acquisition and analysis software, was used to measure flue gas emissions from power plants in Phase 2 and Phase 3. The Lancom III is capable of measuring any of these nine gases: $\mathrm{CO}$ low, $\mathrm{CO}$ high, $\mathrm{O}_{2}, \mathrm{NO}, \mathrm{NO}_{2}, \mathrm{NO}_{\mathrm{x}}, \mathrm{SO}_{2}, \mathrm{H} 2 \mathrm{~S}, \mathrm{CO}_{2}$ and hydrocarbons if the relevant sensors are employed. For this project, four sensors capable of detecting $\mathrm{CO}_{2}, \mathrm{CO}, \mathrm{NO}_{\mathrm{x}}$ and $\mathrm{O}_{2}$ were purchased with the instrument. In addition, the analyzer can calculate combustion efficiency, excess air, and can provide measurement corrections such as oxygen normalization, wet or dry analysis and automatic reading conversions. The instrument measures volumetric concentrations of gases. The installed sensors are calibrated with their respective calibration gases prior to measurement, and checked after the measurement. The instrument was rotated among the project teams in the participating countries.

\section{Results \\ Fuel characteristics}

\section{Coal qualities}

The region uses a variety of coal types as depicted in Table 3. The coals used in South Africa have carbon content ranging from $40.3 \%$ to $57.2 \%$ (ultimate analysis), net calorific value from $14.8 \mathrm{MJ} / \mathrm{kg}$ to $21.5 \mathrm{MJ} / \mathrm{kg}$ and ash content from $20.9 \%$ to $37.09 \%$. These fuel qualities are so varied that using a uniform IPCC default value as an emission factor for all the countries would not be justified.

\section{Diesel quality}

Qualities of diesel were analysed for Zambia and the results show that there is very little difference from the international diesel properties assumed for the IPCC default values (Table 4), hence the energy-based emission factors for Phase 1 were derived using the IPCC default value for diesel power plants. This confirms the International Energy Agency (IEA) assertion, that there is little difference between gas oils from country to country, unlike coal properties (IEA, 2001).

\section{Fuel based emission factors}

Table 5 gives the emission factors for $\mathrm{CO} 2$ as determined by default methods in Phase 1 and as measured in Phase 2. It also gives the $\mathrm{NO}_{\mathrm{x}}$ emission factors for coal fired plants. The various measurements of diesel emissions were consistent within each country but differed from country to country, so only the averages for each country are given. $\mathrm{NO}_{\mathrm{x}}$ emissions were not measured on diesel plants. 
Table 5: Emission factors from Southern African power stations based on fuel energy

\begin{tabular}{|c|c|c|c|c|c|}
\hline \multirow[b]{2}{*}{ Country } & \multirow[b]{2}{*}{ Plant Name } & \multicolumn{2}{|c|}{ Phase 1} & \multicolumn{2}{|c|}{ Phases 2 and 3} \\
\hline & & $\mathrm{CO}_{2}(\mathrm{~kg} / \mathrm{GJ})$ & NOx $(\mathrm{kg} / \mathrm{GJ})$ & $\mathrm{CO}_{2}(\mathrm{~kg} / \mathrm{GJ})$ & NOx $(\mathrm{kg} / \mathrm{GJ})$ \\
\hline \multirow[t]{4}{*}{ South Africa } & Kendal & $94.6(89.5-99.7)^{*}$ & $1.5(0.5-5)^{*}$ & 96.3 & 0.446 \\
\hline & 2005 repeat & & & 97.4 & 0.21 \\
\hline & Lethabo & 94.6 (89.5-99.7) & $1.5(0.5-5)$ & 99.6 & 0.583 \\
\hline & Arnot & $96.1(92.8-100)$ & $1.5(0.5-5)$ & 95.3 & 0.28 \\
\hline \multirow[t]{2}{*}{ Tanzania } & Kiwira & $96.1(92.8-100)$ & $1.5(0.5-5)$ & 73 & 0.125 \\
\hline & Diesel & $74.1(72.6-74.8)$ & $0.6(0.2-2)$ & 73.9 & \\
\hline \multirow[t]{3}{*}{ Zimbabwe } & Bulawayo & 94.6 (89.5-99.7) & $1.5(0.5-5)$ & 97.5 & 0.07 \\
\hline & Harare & 94.6 (89.5-99.7) & $1.5(0.5-5)$ & 97.3 & 2.48 \\
\hline & Hwange & $96.1(92.8-100)$ & $1.5(0.5-5)$ & 97.1 & 0.29 \\
\hline Botswana & Morupule & $96.1(92.8-100)$ & $1.5(0.5-5)$ & 103.0 & 0.32 \\
\hline Mozambique & Diesel & 74.1 (72.6-74.8) & $0.6(0.2-2)$ & 74.2 & \\
\hline Namibia & Diesel & 74.1 (72.6-74.8) & $0.6(0.2-2)$ & 74.8 & \\
\hline Zambia & Diesel & 74.1 (72.6-74.8) & $0.6(0.2-2)$ & 74.4 & \\
\hline
\end{tabular}

Table 6: Emission factors for Southern African power plant based on electrical production

\begin{tabular}{lcccc}
\hline & & Phase 1 & \multicolumn{2}{c}{ Phases 2 and 3 } \\
\hline Country & Plant Name & $\mathrm{CO}_{2}(\mathrm{~kg} / \mathrm{MWh})$ & $\mathrm{CO}_{2}(\mathrm{~kg} / \mathrm{MWh})$ & no $(\mathrm{kg} / \mathrm{MWh})$ \\
\hline South Africa & Kendal & 978 & 1027 & 7.15 \\
\hline & Lethabo & 890 & 1082 & 3.30 \\
\hline Tanzania & Arnot & 952 & 2330 & \\
\hline & Kiwira & 2810 & 858 & \\
\hline & Kigama & 870 & 869 & \\
\hline Mimbabwe & Mtuara & 867 & 858 & - \\
\hline Njambo & 856 & 1450 & \\
\hline Botswana & Sonqua & 910 & 1520 & \\
\hline Mozambique & Bulawayo & 1792 & 1160 & \\
\hline Namibia & Harare & 1693 & 1168 & \\
\hline Zambia & Hwange & 1071 & 890 & \\
\hline & Morupule & 1153 & 819 & \\
\hline & Massinqir & 876 & 1339 & \\
\hline
\end{tabular}

\section{Emission factors on a basis of power produced}

Table 6 gives these emission factors. In this case, some individual diesel-powered stations were identified. There were few reports of $\mathrm{NO}_{\mathrm{x}}$ emissions on the basis of power produced.

\section{Emission factors for methane from coal mining}

The emission factor for the fugitive $\mathrm{CH}_{4}$ from underground coal mining at Hwange in Zimbabwe was found to range from 4.3 to $10 \mathrm{~m}^{3} \mathrm{CH}_{4}$ /ton of coal. The emission factor for underground coal mining in South Africa was $0.5 \mathrm{~m}^{3} \mathrm{CH}_{4} /$ ton coal
(Lloyd \& Cook, 2005). These are generally below the IPCC default values of $10 \mathrm{~m} 3$ to $25 \mathrm{~m}^{3} \mathrm{CH}_{4}$ per ton of coal.

\section{Discussion}

Comparison of the Phase 1 and Phase 2 emission factors given in Tables 5 and 6 shows that:

- The IPCC default factors based on fuel energy represent the South African power plants reasonably well, considering in particular the relatively high ash content of some of the coal. However, when the comparison was on the basis of sent-out energy, the default methods were seriously in error. In part, this was the result 
of the lower-than-normal efficiency caused by the use of high-ash coal.

- The default factors based on fuel energy were reasonably satisfactory for all other plants except for two. At the Tanzanian Kiwira plant, the very low load factor is believed to be the cause of the relatively low emission factor. At the Botswana Morupule plant, the low efficiency is probably the result of employing an old technology.

- The default factors based on power produced were somewhat less than those measured, except for the Tanzanian and Zambian coal plants. In the latter two cases, the emission factors were so high that they could reasonably be described as likely to lie outside the range of any correlations on which the default factors had been based.

- There was excellent agreement between the measured and default factors for all diesel plants studied.

- The NOx data was fairly limited, but in all but two cases the measured values were below the lowest of the IPCC's default values.

The derived national and regional fuel based emission factors for coal-fired stations are given in Table 7. These were derived using a weighted average of fuel based emission factors of the power stations in the region based on generation capacity. It is clear that, due to significance of the South African coal-fired generation capacity, the regional fuelbased emission factor is largely influenced by that for South Africa.

Table 7: Country-wide and regional emission factors for coal-fired stations based on fuel consumed

\begin{tabular}{lcc}
\hline Country & $\mathrm{CO}_{2}(\mathrm{~kg} / \mathrm{GJ})$ & $\mathrm{NOx}(\mathrm{kg} / \mathrm{GJ})$ \\
\hline South Africa & 96.4 & 0.35 \\
\hline Tanzania & 73 & 0.13 \\
\hline Zimbabwe & 97.2 & 0.33 \\
\hline Botswana & 103 & 0.32 \\
\hline Region & 96.5 & 0.35 \\
\hline
\end{tabular}

This situation is, however, likely to change in the near future. Botswana is building about $3600 \mathrm{MW}$ of new coal-fired electrical generation and the Morupule Power Station is to undergo a $600 \mathrm{MW}$ expansion (de Beer, 2007). This means that Botswana will be in a position to contribute nearly $4000 \mathrm{MW}$ to the Southern African Power Pool, and regional emission factors will change as a result of the reduction in the relative strength of the South African supply.

\section{Acknowledgements}

We acknowledge the support provided by Eskom of South Africa for carrying out this research project between 2002 and 2006. In particular, Dr Steve Lennon for establishing the Eskom Climate Change Research Initiative; Clive Turner for launching this project; the Eskom Research Steering Committee for guiding the research activity and providing comments on project reports and publications; Siven Naidoo for continuing to provide the resources required in the project; Jonas Mphepya, Maria Couto and Kubeshnie Naicker for providing competent management support on the Eskom side.

John Keir of Eskom made a significant technical input to the project by undertaking training of project teams on use of the Lancom III gas analyzer at the time of commissioning. He was the lead reviewer of the final project publications.

We also appreciate enormously the support provided in providing data and logistical support by the national utilities in Botswana, South Africa, Tanzania, Zambia, Zimbabwe, Namibia and Mozambique.

\section{References}

IPCC 2006 Guidelines for National Greenhouse Gas Inventories; Volume 2; Energy, Intergovernmental Panel on Climate Change, Geneva http://www.ipccnggip.iges.or.jp/public/gl/invs5a.htm - Accessed October 2007.

Baraddas, S., Morupule Power Station Expansion Project, Engineering News, Apr 20 2007, www.engineeringnews.co.za/article.php?a_id $=107410$ Accessed October 2007.

de Beer, J., The Mmamabula Power Station. Paper No.1:4 in Proceedings Botswana 2007 - The Awakening of a Coal Giant, Gaborone, 28-9 June 2007, Fossil Fuel Foundation, Johannesburg.

Digest of South African Energy Statistics 2005, Department of Minerals \& Energy, Pretoria, ISBN- 09584376-4-5.

Eskom 2006 Annual Report, Johannesburg, 2007.

Fenger J., Fenhann J. and Kilde N., 1990. Danish Budget for Greenhouse gases, NORD 1990, 97, Risoe National Laboratory, Denmark.

International Energy Agency - Part I: Methodology - $\mathrm{CO}_{2}$ emissions from fuel combustion (2001 Edition).

Keir. J. (Jan 1994) Environmental Data (KED) Base from 1982 to 1992 - Report No: RR/P94/004. Internal Eskom Report.

Kritzinger-van Niekerk, Lolette and Moreira, Emmanuel P., 2002 'Regional Integration in Southern Africa: Overview of recent developments', The International Bank for Reconstruction and Development, The World Bank.

Lloyd, P. \& Cook, A., Methane release from South African coal mines, Journal of SA Institute of Mining and Metallurgy, 105 pp 483-490, August 2005.

Mbendi www.mbendi.co.za/indy/powr/af/bo/p0005.htm Accessed November 2007.

Mbendi - www.mbendi.co.za/orgs/cbz6.htm - Accessed November 2007.

Nationsencyclopedia www.nationsencyclopedia.com/ 
Africa/Namibia-ENERGY-AND-POWER.html. Accessed November 2007.

Proceedings Botswana 2007 - The Awakening of a Coal Giant, Gaborone, 28-29 June 2007, Fossil Fuel Foundation, Johannesburg.

Revised 1996 IPCC Guidelines for National Greenhouse

Gas Inventories, Intergovernmental Panel on Climate Change, Geneva www.ipcc-nggip.iges.or.jp/public/ gl/invs5a.htm - Accessed October 2007.

Southern Centre, 1998. Inventory of Greenhouse Gas Emissions from Power Sector- In Options for Greenhouse Gas Mitigation under SADC's Power Sector- Eds R.S. Maya. Southern Centre Series, Harare.

Received 23 January 2009; revised 13 August 2009 